Article

\title{
Basidiospores from Wood-Decay Fungi Transform Laccase Substrates in the Absence of Glucose and Nitrogen Supplements
}

\author{
Gerhard Gramss ${ }^{1, *}$ and Klaus-Dieter Voigt ${ }^{2}$ \\ 1 Institute of Geosciences, Friedrich-Schiller-University, Burgweg 11, D-07749 Jena, Germany \\ 2 Food GmbH Jena, Orlaweg 2, D-07743 Jena, Germany; KD.voigt@gmx.de \\ * Correspondence: Gerhard.gramss@uni-jena.de
}

Received: 16 April 2020; Accepted: 12 May 2020; Published: 14 May 2020

\begin{abstract}
Preparations of bacterial endospores and fungal conidia are applied in biocontrols, biocatalyses, and lignocellulose fermentations. The biocatalytic abilities of basidiospores from mushrooms of the order Agaricales are unknown. To assess their potential in colonizing recalcitrant substrates solely with their inherent resources, spores of the white-rot fungi Stropharia rugoso-annulata (Stru) and Kuehneromyces mutabilis (Kmt, Strophariaceae) were analyzed for surface-bound and internal total carbohydrates, phenols, proteins, minerals, and oxidoreductases to estimate their chemistry and the preconditions to transform the laccase substrates guaiacol and 2,2'-azinobis-(3-ethylbenzthiazoline-6-sulfonate) (ABTS) independent of external glucose and nitrogen. Surfaces of $\mathrm{Stru} / \mathrm{Kmt}$ spores released $\left(\mathrm{mg} \mathrm{kg}^{-1}\right)$ hexoses, 7300/9700; phenols, >62/220; proteins, 21/168; and laccases, 42/0-0.15 $\mu \mathrm{mol} \mathrm{ABTS}{ }^{\bullet+} \mathrm{kg}^{-1} \mathrm{~min}^{-1}$ that mimicked oxidative activities of the resting spores. Milled-spore extracts contained pentoses, 96,600/6750; hexoses, 160,000/15,130; phenols, 452/767; protein, 12,600/924; true laccase, 688/0.30; and enzyme-protein-activating transition metals such as $\mathrm{Cu}$ in concentrations typical of wheat grains. Independent of external $\mathrm{N}$ and $\mathrm{C}$ supply, spores $(<1 \%$ ) germinated in bideionized water, supported by their surface resources. Kmt spores germinated, too, at comparable rates in $\mathrm{N}$-free solutions of glucose and the not immediately metabolizable ABTS and guaiacol. The release of proteins and oxidoreductase(s) by $\mathrm{Kmt}$ spores starting upon germination was higher in guaiacol-incubated idiophase- than in glucose-incubated trophophase-spores and led to the 3-4-fold formation of guaiacol polymerizates and $\mathrm{ABTS}^{\bullet+}$. Constitutive aromatic ring-cleaving dioxygenases in the dormant spore that could be involved in the intrinsic metabolization of guaiacol were not detected. It is concluded that intrinsic resources enable (germinating) spores to release the highly efficient laccases of basidiomycetes and to transform aromatic compounds in the absence of sugar amendments. Spores show therefore plant seed-like autonomy in nutrient modification and acquisition during the early stages of the colonization of inert substrates.
\end{abstract}

Keywords: basidiospore chemistry; biocatalysis; autonomous germination; carboxylate exudation; laccase; wood-decay fungi

\section{Introduction}

Commercial preparations of bacterial endospores, of conidia and spores from ascomycete fungi and yeasts, and of conidia from the basidiomycete Peniophora gigantea (all referred to as spores) are applied in the biocontrol of fungal and insect pests of crop plants [1-3] and in the control of weeds [4], the butt rot of conifers [5], and populations of (malaria) mosquitos [6-8]. Spore preparations of vesicular-arbuscular (VA) mycorrhizal fungi, Rhizobium, and Azotobacter spp. promote root and shoot growth in certain plant species $[9,10]$. Spores also serve as inocula in the large-scale fermentation of agricultural and 
industrial organic wastes and in the processing of lignocelluloses to value-added products [11-13]. As biocatalysts, spores perform redox reactions, hydrolyses, isomerizations, double-bond formations, and cleavage of C-C linkages [14]. No comparable niches have been occupied by basidiospores derived from fruitbodies of homobasidiomycetes whose basic chemistry, energy resources, and biocatalytic activities are largely unknown. Thus, their resulting degree of nutritional autonomy or dependence on external nutrients upon the colonization of recalcitrant substrates attracted no attention.

Across the fungal kingdom, spore remoistening initiates respiration and the metabolic access to internal storage compounds such as lipids $[15,16]$, carbohydrates represented mainly by mannitol, trehalose, (cell wall) polysaccharides [17-19], and traces of fructose and sucrose [18]. Internal generation of, and the external supply with, D-glucose or its analogous pyranose sugars [20] provide the sources of energy [21] and the material for germination and cell wall synthesis. D-glucose is derived from D-trehalose deposits [21] and generated from acetyl-CoA, which is formed during the beta-oxidation of the fatty acids component of spore lipids. Its entry into tricarboxylic acid or the glyoxylate cycle leads to the formation of malate as another hexose precursor [16,22]. Spores also fix $\mathrm{CO}_{2}[23,24]$ and volatiles of short-chain alkanes [25] or microorganisms [26] to serve as sources of external carbon and of bioactive compounds. Cellulases, cutinases, esterases, and pectinases are released by the remoistened spores of plant pathogenic fungi upon leaf contacts to initiate attachment and appressorium formation [27-29]. Unlike the dormant and melanized basidiospore of the wood-decay fungus Kuehneromyces mutabilis (Schff.:Fr.) Sing. \& Smith whose distinct shape is retained on outgrowth of a germ tube, basidiospores of the brown-rot fungus Lenzites trabea are not constitutively dormant, they germinate in the presence of a growth substrate within 4 to $5 \mathrm{~h}$ and turn completely into hyphae without striking changes in subcellular and cell wall organization [30,31]. The incorporation of glucose, acetate, and succinate at zero time, without any lag, suggests the presence of fully active enzyme systems in the spore. Remoistening initiates the slow formation of RNA and proteins. Growth media stimulate the synthesis of DNA and of Fe-porphyrins [31] indicative of peroxidases [32].

It is apparent that comparable metabolic activities in the pre-germination basidiospore presuppose considerable resources in storage compounds. Spores of Agaricus bisporus contained 17-19\% lipids and $12 \%$ soluble carbohydrates in the cytosol [17]. Spores of Ganoderma lucidum contained $8.65 \%$ free sugars, increasing to $14.5 \%$ after hydrolysis [18]. Concentrations of protecting (phenolic) antimicrobials and reactive radical scavengers and of (enzyme) proteins and their associated minerals were not reported.

Up to $33-50 \%$ of proteins are presumably metalloproteins linked with (transition) metal cations [33,34] and comprise enzyme, transport, storage, signal transduction, and metal sensing proteins. Among intra- and extracellular enzymes from all six enzyme classes, nearly $50 \%$ of them associate with metals to function [35,36]. Upon the degradation of lignin by white-rot fungi such as K. mutabilis, nutrient acquisition is initiated by the consecutive one-electron oxidation (abstraction of $\mathrm{H}^{+} / \mathrm{e}^{-}$) from phenolic, and in concert with redox mediators, from non-phenolic lignin structures by oxidoreductase enzymes. They form the respective phenoxy and aryloxy radicals that stabilize themselves in subsequent polymerizations, disproportionations, and fragmentations of the lignin polymer. The reactions are mainly catalyzed by glycoproteins of the polyphenoloxidase (PO) complex which comprises laccases, tyrosinases, and catechol oxidases with 2-4 Cu atoms in their catalytic centers. In addition, Mn-dependent peroxidases (MnP) operate with protoporphyrin IX $\left(\mathrm{Fe}^{3+} / \mathrm{Fe}^{4+}\right.$ redox cycle) as the prosthetic group in their catalytic center, use Mn cations as redox mediators, and are stabilized by $\mathrm{Ca}^{2+}$ cations (compare [32,37-40] for more details and the respective redox cycles). The expression of oxidoreductases in basidiospores of wood-decay fungi or the application of the spores as biocatalysts was apparently not investigated.

A report on extracellular laccase activities of Trichoderma atroviride conidia formed on a laccase-positive mycelial mat [41] prompted a test with K. mutabilis basidiospores, collected by placing mushroom caps in Petri dishes. Some spore prints within a dish were laccase- and MnP-negative so that spores from enzyme-positive sectors were suspect of contamination by enzymatic effluents from the cap plectenchyma but were not enzymatically active by themselves. Similar smear contact 
effects may add to the biocatalytic performance of many spore sources in use and support those of wood-decay fungi in their initial attack on inert natural substrates.

In this study, basidiospores of the lignocellulose degrading white-rot fungi K. mutabilis (6-7.5 $\mu \mathrm{m}$ long) and Stropharia rugoso-annulata Farlow emend Murrill (10.4-13 $\mu \mathrm{m}$ long) were collected from suspended mushroom caps to obtain free-fallen spores devoid of smear contaminations and microbial infections [42]. The in- and outside concentrations in hydrocarbons, phenols, proteins, and oxidoreductase enzymes with their associated (trace) metals were determined for the spore prints and correlated with their ability to transform the laccase substrates guaiacol and 2,2'-azinobis-(3-ethylbenzthiazoline-6-sulfonate) (ABTS) prior to germination in glucose- and nitrogen-free media and thus without the aid of external nutrients. Furthermore, their germination rates were determined in the presence of glucose, ABTS, and guaiacol as well as in their absence. The goal of this study was to assess whether the sole intrinsic storage compounds confer a plant seed-like nutritional autonomy to basidiospores in the initial establishment on recalcitrant lignocellulosics devoid of easily accessible nutrients.

\section{Materials and Methods}

\subsection{Spore Sources}

Sporulating basidiomes of S. rugoso-annulata (Stru) growing on composted wood chips in the field were collected in spring and fall 2014. Basidiomes of K. mutabilis (Kmt) were provided by perennial field cultures established on leafwood stem segments [43] (Figure 1).

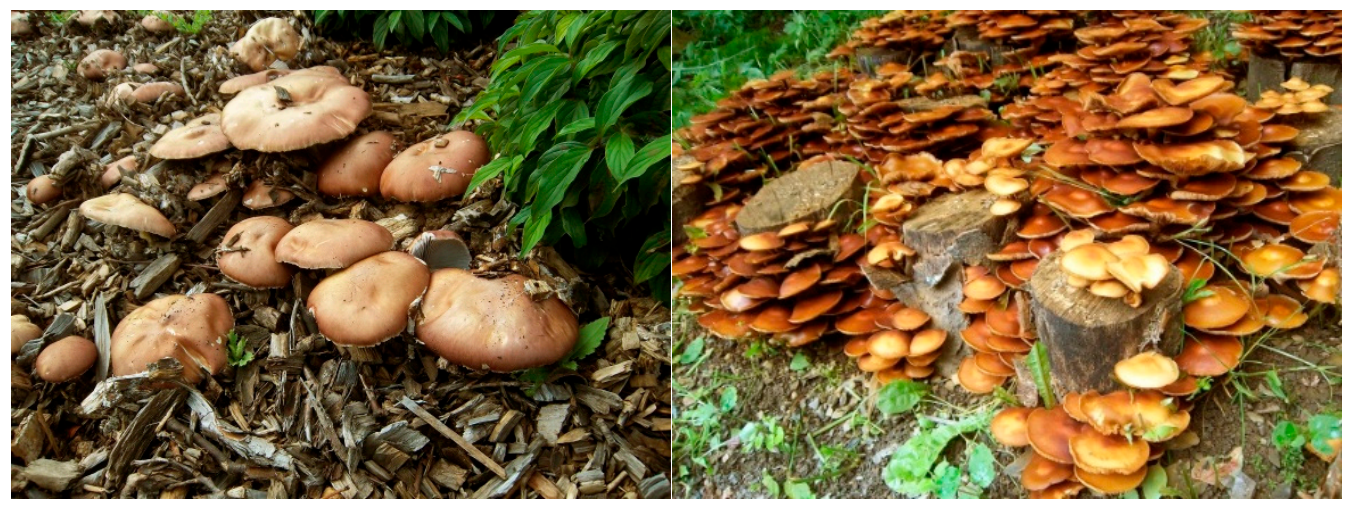

Figure 1. Basidiomes of S. rugoso-annulata (left) and K. mutabilis (Strophariaceae) (right).

\subsection{Spore Sampling and Washing}

Mature basidiomes were fixed inside to the lids of autoclaved 0.3-L packing jars to avoid smear contaminations of the free-falling spores with plectenchyma effluents. The spores were weighed into 2-mL plastic microtubes and washed twice in 1.5-mL aliquots of bideionized water amended with the anionic detergent Fit (Fit GmbH, Hirschfelde, Germany; $5 \mathrm{mg}$ per $10 \mathrm{~mL}$ ). They were then rinsed twice in bideionized water. In a second treatment, water soluble compounds from spore surfaces were collected in 4 consecutive washings within $70 \mathrm{~min}$. The spore suspensions were vigorously shaken for $10 \mathrm{~min}$ and centrifuged at 14,000 $\mathrm{g}$ for $5 \mathrm{~min}$. Supernatants were collected for analyses.

\subsection{Spore Incubation}

Quadruplicate sets of wide-necked Erlenmeyer flasks $(100 \mathrm{~mL})$ were washed twice in bideionized water, filled with $6 \mathrm{~mL}$ of sole or combined glucose $\left(5 \mathrm{~g} \mathrm{~L}^{-1}\right.$; Merck KGaA, Darmstadt, Germany), guaiacol (133 $\mathrm{mg} \mathrm{L}^{-1}$ ), or 2,2' -azinobis-(3-ethylbenzthiazoline-6-sulfonate) (ABTS, $224 \mathrm{mg} \mathrm{L}^{-1}$ ) (Fluka) solutions of highest purity (Table 1 ) and autoclaved at $121^{\circ} \mathrm{C}$ for $30 \mathrm{~min}$. To obtain surface-sterile prints of $K$. mutabilis basidiospores that were also believed to be clean of smear contaminations with 
enzymes from the mushroom gills, mature cap segments $2 \mathrm{~cm}$ in diameter were pinned inside to the cotton wool stoppers of the flasks with the gills pointing downwards [42] until rust-brown spore deposits indicated the release of 3 to $4 \mathrm{mg}$ spores per flask. In a further treatment, the spore input was held below $0.3 \mathrm{mg}$. Duplicate control flasks were run without spore deposits. The samples were incubated at 15 to $19{ }^{\circ} \mathrm{C}$ in the dark until reddish-brown (guaiacol) or green (ABTS) stain reactions revealed oxidative enzyme activities. Concentrations of the respective transformation products and the current enzyme activities were determined by spectrophotometry (Helios Beta; Unicam UV-Vis; Cambridge, UK). Spore germination was followed microscopically at 2 and $7 \mathrm{~d}$ by retrieving $0.05-\mathrm{mL}$ aliquots with aseptic pipettes.

Table 1. Mean concentrations ( $\mu \mathrm{g} \mathrm{L}^{-1} \pm \mathrm{SD} ; n=2$ ) in the high-purity incubation media of metal cations which are commonly associated with laccase and MnP metalloenzymes (ICP-MS data).

\begin{tabular}{ccccc}
\hline Medium & Ca & Cu & Fe & Mn \\
\hline Bideionized water & $<10$ & $0.39 \pm 0.12$ & $0.12 \pm 0.04$ & $0.01 \pm 0.01$ \\
Glucose $5 \mathrm{~g} \mathrm{~L}^{-1}$ & $34 \pm 7$ & $1.3 \pm 0.32$ & $0.27 \pm 0.08$ & $0.13 \pm 0.04$ \\
${\text { Guaiacol 133 } \mathrm{mg} \mathrm{L}^{-1}}^{-1}$ & $34 \pm 4$ & $1.4 \pm 0.12$ & $0.45 \pm 014$ & $0.08 \pm 0$ \\
ABTS 224 $\mathrm{mg} \mathrm{L}^{-1}$ & $64 \pm 1$ & $1.8 \pm 0$ & $0.61 \pm 0.02$ & $0.34 \pm 0.06$ \\
Spore suspension $^{\text {a }}$ & $111 \pm 16$ & $2.4 \pm 0.92$ & $3.8 \pm 1.2$ & $1.66 \pm 0.12$ \\
\hline
\end{tabular}

a Unwashed and free-fallen $\mathrm{Kmt}$ basidiospores $\left(0.67 \mathrm{~g} \mathrm{~L}^{-1}\right)$ infused in bideionized water for $2 \mathrm{~d}$ released thus (mg kg ${ }^{-1}$ spores): $\mathrm{Ca}, 152 \pm 28 ; \mathrm{Cu}, 3 \pm 0.9 ; \mathrm{Fe}, 5.5 \pm 1.3 ; \mathrm{Mn}, 2.5 \pm 0.13$.

Using 1-cm cuvettes in preliminary assays, washed and unwashed spores were incubated in 1-mL aliquots of bideionized water, glucose, or ABTS solution under filtered-air conditions for at least 5 days. The initially hydrophobic spores sank generally to the bottom of the vessels and were not actively aerated to confine the fixation of carbon from aerial $\mathrm{CO}_{2}$ (Figure 2).

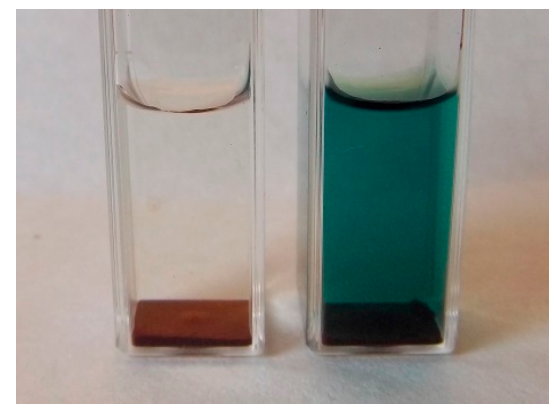

Figure 2. Formation of the green $\mathrm{ABTS}^{\bullet+}$ by basidiospores of $K$. mutabilis in 1-cm cuvettes. Left, water control.

\subsection{Spore Cracking}

The bullet blender PM 400 (Retsch, 42781 Haan, Germany) fitted with 20 steel balls $10 \mathrm{~mm}$ in diameter was used to break 250-mg samples of washed spores suspended in $1 \mathrm{~mL}$ of $0.1 \mathrm{M} \mathrm{KH}_{2} \mathrm{PO}_{4}$ buffer at $400 \mathrm{rpm}$ over $1 \mathrm{~h}$. Spore fragments $\leq 1-10 \mu \mathrm{m}$ were recovered with the buffer and stored at $-20{ }^{\circ} \mathrm{C}$.

\subsection{Spectrophotometric Assays with Chromogenic Enzyme Substrates}

Oxidation of ABTS by potential mixtures of laccase (EC 1.10.3.2), catechol oxidase (EC 1.10.3.1), and tyrosinase (EC 1.14.18.1) enzymes [44] in spore supernatants amended with glucose, guaiacol, or a combination of both was followed by an increase in absorbance at $\mathrm{A}_{420}\left(\varepsilon_{420}=36,000 \mathrm{M}^{-1} \mathrm{~cm}^{-1}\right)$ in a reaction mixture of $\mathrm{pH} 5$ containing $\mathrm{KH}_{2} \mathrm{PO}_{4}$ buffer $(0.033 \mathrm{M})$ and ABTS $(0.4 \mathrm{mM})$. Concentrations of guaiacol oligomers in spore supernatants or in separate reaction mixtures of $\mathrm{pH} 5$ with $0.6 \mathrm{mM}$ guaiacol were recorded at $\mathrm{A}_{436}\left(\varepsilon_{436}=6400 \mathrm{M}^{-1} \mathrm{~cm}^{-1}\right.$; [45]. The oxidation of DL-DOPA (14mM) in a phosphate 
buffer of $\mathrm{pH} 6$ was recorded as an increase in absorbance at $475 \mathrm{~nm}\left(\varepsilon_{475}=3600 \mathrm{M}^{-1} \mathrm{~cm}^{-1}\right.$; [46] and confirmed by controls amended with $2 \mathrm{mg} \mathrm{mL}^{-1}$ of the tyrosinase inhibitor, gallic acid [47]. Activities of manganese-dependent peroxidase (MnP, EC 1.11.1.13) for the non-stained glucose supernatants were determined as an increase in $\mathrm{A}_{265}\left(\varepsilon_{270}=11,590 \mathrm{M}^{-1} \mathrm{~cm}^{-1}\right)$ in a reaction mixture of $0.15 \mathrm{mM} \mathrm{H}_{2} \mathrm{O}_{2}$, $0.2 \mathrm{mM} \mathrm{MnSO}_{4} \times \mathrm{H}_{2} \mathrm{O}$, and $50 \mathrm{mM} \mathrm{Na}$-malonate at pH 4.5 [48,49]. Basidiospore homogenates were tested for activities of the aromatic-ring cleavage catalysts, catechol 2,3-dioxygenase (EC 1.13.11.2), and protocatechuate 4,5-dioxygenase (EC 1.13.11.8). More details are provided in a separate paper [50].

\subsection{Protein and Rest Glucose}

Concentrations of protein in spore supernatants were recorded at $\mathrm{A}_{595}$ with Bradford reagent based on Coomassie Brilliant Blue G-250 [51]. Non-consumed rest glucose was determined with Medi-Test Glucose strips $\left(0.1->10 \mathrm{~g} \mathrm{~L}^{-1}\right.$; Macherey-Nagel, Düren, Germany) responding to concentrations $<0.01 \mathrm{~g} \mathrm{~L}^{-1}$ within $10 \mathrm{~min}$.

\subsection{Pentose and Hexose Sugars}

Washing fluids of intact spores and supernatants of washed and cracked spores were used for the colorimetric quantitation of in- and outside pentose and hexose sugars, oligosaccharides, and their methylated derivatives [52]. A reaction mixture of $0.2 \mathrm{~mL}$ supernatant, $0.2 \mathrm{~mL}$ of a $5 \%(w / w)$ aqueous solution of phenol, and $1 \mathrm{~mL}$ concentrated $\mathrm{H}_{2} \mathrm{SO}_{4}$ was left reacting at $25^{\circ} \mathrm{C}$ for $10 \mathrm{~min}$. Absorbance was determined at $490 \mathrm{~nm}$ and compared to blank samples in which the supernatant had been replaced by water. Absorbance peaks were determined by scanning spectrophotometry to discriminate between peaks at $480 \mathrm{~nm}$ (for pentoses, methylpentoses, uronic acids), and 485 to $490 \mathrm{~nm}$ (for hexoses and their methylated derivatives). Calibration was performed with 10, 50, and $150 \mathrm{mg} \mathrm{L}^{-1}$ aqueous xylose and sucrose solutions, respectively.

\subsection{Total Phenols}

Fast Blue B salt (tetrazotized o-dianisidine, Acros, Geel, Belgium) reacted with 1-naphthol and other hydroxylated aromatic compounds to form coloured products whose maximum absorbance was in the range 530 to $618 \mathrm{~nm}$ [53]. In adaptation, spore supernatants of $0.3-1 \mathrm{~mL}$ were filled up to $1.9 \mathrm{~mL}$ with $0.2 \mathrm{M} \mathrm{KH}_{2} \mathrm{PO}_{4}$ buffer $\mathrm{pH} 4.5$ in 1-cm glass cuvettes by determining their absorbance correction values at $\mathrm{A}_{530}$. Then $0.1 \mathrm{~mL}$ of a $\mathrm{KH}_{2} \mathrm{PO}_{4}$-buffered and freshly prepared Fast Blue $\mathrm{B}$ solution (10 $\mathrm{mg} \mathrm{mL}^{-1}$ ) was added and shaken to record the rapidly increasing absorbance value at $10 \mathrm{~s}$. Results were expressed in pyrogallol equivalents.

\subsection{HPLC-MS Analysis of Guaiacol Transformation Products}

Oligomers in guaiacol-amended spore supernatants were analyzed with an Agilent 1100 HPLC (Agilent Technologies) equipped with a Bruker Esquire 6000 Ion Trap Mass Spectrometer detector (Bruker Daltonics, Bremen, Germany) and a Nucleodur Sphinx RP $5 \mu \mathrm{m}$ column $(250 \times 4.6 \mathrm{~mm}, 5 \mu \mathrm{m}$, Macherey-Nagel, Düren, Germany). The solvent systems comprised $0.2 \%$ formic acid in water (A) and acetonitrile (B) used in gradient mode at a flow rate of $1 \mathrm{~mL} \mathrm{~min}-1$ at $25^{\circ} \mathrm{C}$. The gradient was as follows: $100 \%$ A (5 min), 0-75\% B (25 min), 75-100\% B (0.1 min), 100\% B (4.9 min), and 100\% A (4.9 $\mathrm{min}$ ). The mass spectrometer was operated in an alternating ionization mode in the range $\mathrm{m} / \mathrm{z}$ $60-1400$. Skimmer voltage, $\pm 35 \mathrm{eV}$; capillary exit voltage, $\pm 102 \mathrm{eV}$; capillary voltage, $\pm 4000 \mathrm{~V}$; nebulizer pressure, $35 \mathrm{psi}$; drying gas, $11 \mathrm{~L} \mathrm{~min}^{-1}$; gas temperature, $330{ }^{\circ} \mathrm{C}$.

\subsection{HPLC-MS/MS Analysis of Carboxylic Acids}

Carboxylic-acid exudates of submerged and non-germinated spores were analyzed with a Shimadzu LC-20 AD HPLC with API 4000 mass spectrometer (Applied Biosystems) and Phenomenex Luna $3 \mu$ PFP (2) $100 \mathrm{~A}$ column $150 \times 3.00 \mathrm{~mm}$. The mobile phases used in gradient mode comprised 
the solvents A (water: methanol 99:1 with $5 \mathrm{mM}$ ammonium acetate) and B (methanol: acetic acid 99:1 with $5 \mathrm{mM}$ ammonium acetate). Aliquots of $5 \mu \mathrm{L}$ were analyzed within $15 \mathrm{~min}$ at $30{ }^{\circ} \mathrm{C}$ of column temperature.

\subsection{Spore Mineral Content}

Duplicate 300-mg samples of unwashed basidiospores were microwave digested in $\mathrm{HNO}_{3}(4 \mathrm{~mL})$ and $\mathrm{H}_{2} \mathrm{O}_{2}(1 \mathrm{~mL})$ and diluted to $150 \mathrm{~mL}$ with bi-deionized water. The solutions were analyzed by Inductively Coupled Plasma Mass Spectrometry (ICP-MS; Thermo, X series, Thermo Fisher Scientific, Dreieich, Germany). Argon was used as the carrier gas. One-point calibration was done with the metal standard solutions, Merck VI and Merck XXI (Merck, Darmstadt, Germany), diluted to 5\%. Resulting detection limits in $\mathrm{mg} \mathrm{kg}^{-1}$ dry weight (DW) were as follows: 0.0005, Th; 0.002, CdCoCsU; 0.005, Cr; 0.01, AsMnPb; 0.02, CuSr; 0.03, BaNiZn; 0.04, Fe; 0.1, AlMg; 0.4, KNa; 1, P; and 3, Ca.

\subsection{Statistical Treatments}

SPSS 8.0 software (SPSS Inc., Chicago, IL, USA) was used to calculate standard deviations and confidence levels of duplicate to quadruplicate results from two to four replicates of the individual experiments.

\section{Results}

\subsection{In- and Outside Concentrations of Major Organic Spore Constituents}

The large resting spores of Stru released surprising activities of laccase, high concentrations of carbohydrates, little phenolics, and non-significant traces of protein into the first washing fluid (Table 2). Apart from surface phenolics, most constituents declined to marginality in the fourth wash. Internal concentrations in carbohydrates $>>$ protein $>>$ phenolics and laccase surpassed the outside resources by more than an order of magnitude. Reaction with the p-diphenol and syringaldazine identified oxidoreductase as the true functional endolaccase [54]. Chromogenic tests for internal tyrosinases and Mn peroxidases were negative. The small melanized spores of Kmt released some carbohydrates, protein, and almost non-removable stocks of phenolics into the yellowing first wash, completed by negligible-to-lacking traces in surface laccase (Table 2). Similarly, most of these compounds from inside the spores lagged far behind those found in Stru which applied in particular to the negligible endolaccase activities.

Table 2. Laccase activity ( $\mu \mathrm{mol} \mathrm{ABTS}{ }^{\bullet+} \mathrm{kg}^{-1} \mathrm{~min}^{-1} \pm \mathrm{SD}$ ), and the concentrations of protein, carbohydrate, and total phenol $\left(\mathrm{mg} \mathrm{kg}^{-1}\right)$ in the four consecutive washing fluids and inside the washed and milled basidiospores of S. rugoso-annulata and K. mutabilis $(n=2-4)$.

\begin{tabular}{|c|c|c|c|c|c|}
\hline Species & Extract & Laccase & Protein & Carbohydrate & Total Phenol ${ }^{\mathrm{c}}$ \\
\hline \multirow{6}{*}{ Stropharia } & 1. Wash & $32.8 \pm 3.90$ & $21 \pm 99$ & $7270 \pm 33^{a}$ & $18.5 \pm 2.1$ \\
\hline & 2. Wash & $7.38 \pm 2.56$ & ND & ND & $18.8 \pm 3.6$ \\
\hline & 3. Wash & $1.34 \pm 1.34$ & ND & ND & $13.3 \pm 1.8$ \\
\hline & 4. Wash & $0.28 \pm 0.20$ & ND & ND & $10.9 \pm 0.1$ \\
\hline & Total 1-4 & $41.7 \pm 4.9$ & $21 \pm 99$ & $7270 \pm 33^{a}$ & $61.5 \pm 4.6$ \\
\hline & Inside concentr. & $688 \pm 84$ & $12,600 \pm 405$ & $\begin{array}{l}160,000 \pm 2670^{a} \\
96,600 \pm 1200^{b}\end{array}$ & $452 \pm 53$ \\
\hline \multirow{6}{*}{ Kuehneromyces } & 1. Wash & $0.15 \pm 0.15$ & $168 \pm 121$ & $9730^{a}$ & $68.3 \pm 6.3$ \\
\hline & 2. Wash & ND & ND & ND & $73.6 \pm 6.9$ \\
\hline & 3. Wash & ND & ND & ND & $36.9 \pm 2.5$ \\
\hline & 4. Wash & ND & ND & ND & $40.2 \pm 0.5$ \\
\hline & Total 1-4 & $0.15 \pm 0.15$ & $168 \pm 121$ & $9730^{a}$ & $219 \pm 9.7$ \\
\hline & Inside concentr. & $0.30 \pm 0.03$ & $924 \pm 49$ & $\begin{array}{c}15,130 \pm 490^{a} \\
6750 \pm 56^{b}\end{array}$ & $767 \pm 27$ \\
\hline
\end{tabular}

${ }^{a}$ Expressed in sucrose equivalents; ${ }^{b}$ in xylose equivalents; ${ }^{c}$ in pyrogallol equivalents. ND, not detected. 
Absorbance spectra of carbohydrates displayed a single peak for hexose sugars at $\mathrm{A}_{485}$ for the first wash of both spore sources (Figure 3; compare Section 2.2). Internal carbohydrates of washed Stru spores showed uniformly high absorbance values from $\mathrm{A}_{475}$ to $\mathrm{A}_{480}$ for pentoses which passed over to $A_{485}$ to $A_{494}$ values for hexoses. Those of Kmt spores formed single peaks at $A_{479}$ and $A_{484}$.

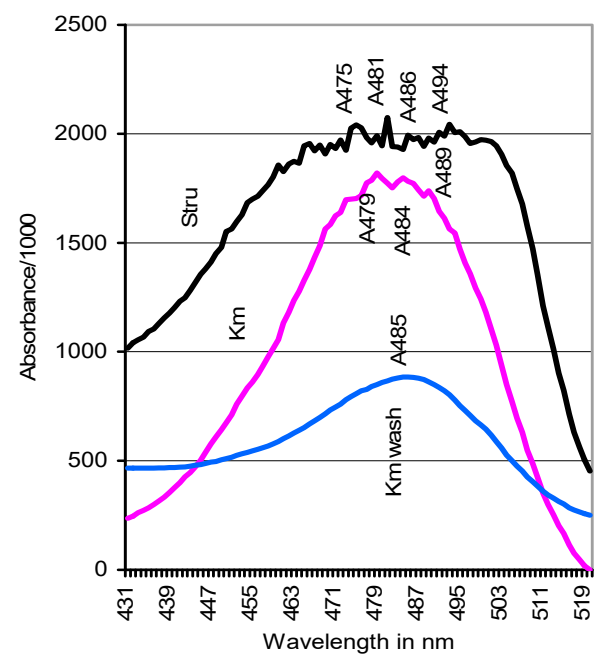

Figure 3. Absorbance spectra indicative of the expression of pentoses and hexoses in the internal carbohydrate pool of washed S. rugoso-annulata and K. mutabilis spores and in the first wash of $\mathrm{Kmt}\left(\mathrm{A}_{485}\right)$.

\subsection{Concentrations of Enzyme-Associated, Essential Minerals in Spores}

Table 3 presents the outregulated metal load of wheat grains as the only available landmark for tolerable concentration spans which ensures, e.g., the adequate supply of the germinating seedling by avoiding metal stress $[55,56]$. Unwashed spores of $\mathrm{Kmt}$ as organisms adapted to the same geochemical environment were moderately higher in $\mathrm{Co}, \mathrm{Fe}, \mathrm{K}, \mathrm{Mn}$, $\mathrm{Na}$ and $\mathrm{Ni}$ but not in the other minerals.

Table 3. Out-regulated concentrations ( $\mathrm{mg} \mathrm{kg}^{-1} \pm \mathrm{SD}$ by dry weight (DW)) of essential, enzyme-asssociated minerals in unwashed basidiospores of S. rugoso-annulata and K. mutabilis in comparison to those in wheat grains $(n=2)$.

\begin{tabular}{ccccc}
\hline Element & Stropharia & Kuehneromyces & Presence in Enzymes $^{\mathbf{a}}$ & Concentration Ranges in Whole Wheat Grains $^{\mathbf{b}}$ \\
\hline $\mathrm{Ca}$ & $755 \pm 44$ & $277 \pm 19$ & 2 & $280-540$ \\
$\mathrm{Cd}$ & $0.860 \pm 0.012$ & $0.850 \pm 0.003$ & $(1$ enzyme $)$ & $0.02-3(0.05-0.4)$ \\
$\mathrm{Co}$ & $0.094 \pm 0.002$ & $0.705 \pm 0.006$ & 1 & $<0.03$ \\
$\mathrm{Cu}$ & $20.3 \pm 0.3$ & $24 \pm 0.6$ & 1 & $11-14(2-20)$ \\
$\mathrm{Fe}$ & $385 \pm 5$ & $199 \pm 4$ & 8 & $40-64$ \\
$\mathrm{~K}$ & $6200 \pm 42$ & $8160 \pm 32$ & 16 & $4100-6500$ \\
$\mathrm{Mg}$ & $640 \pm 4$ & $1140 \pm 3$ & 6 & $1160-1700$ \\
$\mathrm{Mn}$ & $28 \pm 0.2$ & $73.5 \pm 1.2$ & 0.5 & $18-34(14-30)$ \\
$\mathrm{Na}$ & $304 \pm 4$ & $92 \pm 6$ & 0.5 & $30-50$ \\
$\mathrm{Ni}$ & $3.43 \pm 0.32$ & $13 \pm 0.07$ & 9 & $0.18-1.4(0.1-3)$ \\
$\mathrm{P}$ & $5470 \pm 64$ & $5150 \pm 43$ & $75 \pm 0.8$ & $4000-5300$ \\
$\mathrm{Zn}$ & $79 \pm 2$ & & $35-190(10-100)$
\end{tabular}

${ }^{a}$ Percentage of enzymes from all six enzyme classes with which the metal cation associates [36]. ${ }^{b}$ Adapted from Gramss and Voigt [43,56]. In parentheses, normal spans of mineral concentrations in dry food crops [57].

Of the metals present in higher numbers of enzymes, Fe and Mn as the co-factors of fungal class II peroxidases but not $\mathrm{Mg}$ and $\mathrm{Zn}$ clearly surpassed the concentration limits known from grain crops (Table 3). Contemporarily, the unwashed Kmt spores released 55\%/13\%/2.8\%/3.4\% of their total Ca, Cu, Fe and Mn resources into bideionized water (Table 1). Unwashed spores of Stru were considerably higher in the enzyme-associated $\mathrm{Fe}$ and $\mathrm{Na}$ and moderately elevated in $\mathrm{Ca}$ and $\mathrm{Co}$ but did not leave the concentration range of grains in regard to the other essential elements (Table 3). 


\subsection{Basidiospore Germination under Nutrient-Limited Conditions in 1-cm Cuvettes}

The 4-mg samples of washed and unwashed basidiospores deposited at the bottom of cuvettes (Figure 2) started germinating late at the second day in a 5\% glucose solution (1 mL) of high purity (Table 1) but not yet in the bideionized water. At $5 \mathrm{~d}$, both the spores of Stru and Kmt had formed vertical hyphae on the bottom deposits as well as hyaline floating clusters of spores connected by clamped hyphae. Further spores formed germ tubes of 2.5 to $25 \mu \mathrm{m}$ in length. Whereas the germination rates were estimated to amount to $35 \%$, the use of unwashed spores led to the formation of the 4- to 5 -fold quantity of visible hyphae (Table 4). Of the spores of Stru suspended in bideionized water, $<1 \%$ o formed stagnating hyphal tips of $2.5 \mu \mathrm{m}$ at the germ porus, with a significantly higher rate in the unwashed treatment. Similarly, unwashed $\mathrm{Kmt}$ spores developed the hyphal tips at an extremely lower percentage while washed spores failed to germinate (Table 4).

Table 4. Comparative germination of unwashed and washed basidiospores $\left(4 \mathrm{~g} \mathrm{~L}^{-1}\right)$ in 1 -mL aliquots of glucose solution $\left(5 \mathrm{~g} \mathrm{~L}^{-1}\right)$ and bideionized water in 1 -cm cuvettes at $23^{\circ} \mathrm{C}$ for $5 \mathrm{~d}(n=3-5)$. Mrel, visually estimated relative mycelial quantity.

\begin{tabular}{|c|c|c|c|}
\hline Medium & Treatment & Stropharia & Kuehneromyces \\
\hline \multirow[b]{2}{*}{ Glucose solution } & Unwashed & $\begin{array}{l}\text { On spore deposits, vertical hyphae } \\
1.5-3 \mathrm{~mm} \text {, and floating mycelia up } \\
\text { to } 3 \mathrm{~mm} \text {; Mrel = } 1\end{array}$ & $\begin{array}{l}\text { On spore deposits, vertical hyphae } 1-1.5 \\
\mathrm{~mm} \text {, and floating mycelia up to } 1.5 \mathrm{~mm} ; \\
\text { Mrel = } 1\end{array}$ \\
\hline & Washed & $\begin{array}{l}\text { Vertical hyphae } 0.7 \mathrm{~mm} \text {, no } \\
\text { floating mycelia; Mrel }=0.2 \text {. Both } \\
\text { germination rates around } 35 \% \\
\text { rest glucose, } 4.5 \mathrm{~g} \mathrm{~L}^{-1}\end{array}$ & $\begin{array}{c}\text { Vertical hyphae } 0.5-1 \mathrm{~mm} \text { and traces of } \\
\text { floating mycelia; Mrel }=0.25 \text {. Both } \\
\text { germination rates around } 35 \% \text {; rest glucose, } \\
4.5 \mathrm{~g} \mathrm{~L}^{-1}\end{array}$ \\
\hline \multirow{2}{*}{ Water } & Unwashed & $\begin{array}{c}<1 \% \text { of spores with germ tubes } \\
2.5 \text { (to } 25) \mu \mathrm{m} ; \text { Mrel = } 1\end{array}$ & $<<1 \%$ of spores with germ tubes $2.5 \mu \mathrm{m}$ \\
\hline & Washed & $\begin{array}{c}<1 \% \text { of spores with germ tubes } \\
2.5 \text { (to } 25) \mu \mathrm{m} ; \text { Mrel }=0.6\end{array}$ & No germinating spores \\
\hline
\end{tabular}

\subsection{Release of Carboxylic Acids by Pre-Germination Spores in Cuvettes}

Incubating 4-mg samples of unwashed spores in 1-mL aliquots of bideionized water or a 5\%o glucose solution of high purity as above led to the acidification of the latter by non-germinated Stru $>$ Kmt spores even within 12-20 h (Figure 4). Observation of the cultures over $14 \mathrm{~d}$ found the spores of $\mathrm{Stru} / \mathrm{Kmt}$ united at $\mathrm{pH}$ 2.6/2.86 in glucose solution and alkalinized at $\mathrm{pH} 7.3$ in water.

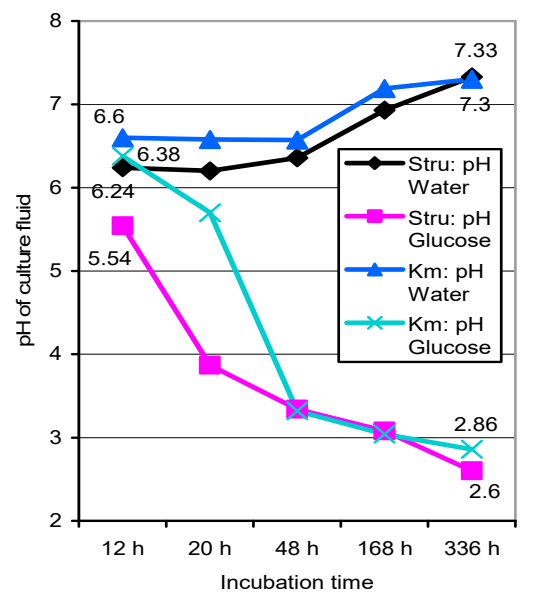

Figure 4. $\mathrm{pH}$ shifts in aqueous and glucose-amended 1-mL suspensions of unwashed S. rugoso-annulata and $K$. mutabilis basidiospores $\left(4 \mathrm{~g} \mathrm{~L}^{-1}\right)$ incubated in cuvettes over $336 \mathrm{~h}$. Values deviate $<0.1$ to $0.2 \mathrm{pH}$ units from those of washed basidiospores.

Incubation of spores with the pure guaiacol solution in 1-cm cuvettes did not result in significant $\mathrm{pH}$ changes. Washed Stru spores acidified glucose medium with the aliphatic carboxylates citrate, 
fumarate, malate, and succinate (Table 5) which are typical of tricarboxylic acid and the glyoxylate cycle [22]. The early presence of glycolate, malonate, and tartrate results from the respective enzymatic derivations. Traces of the aromatics, benzoic, and gallic acid were also found. They appeared at lower concentrations in the first wash of Stru spores, too, combined with succinate (Table 5).

Table 5. Carboxylic acids ( $\mathrm{mg} \mathrm{kg}^{-1}$ spores, $\left.n=1\right)$ released by unwashed and non-germinated spores of S. rugoso-annulata $\left(6.7 \mathrm{~g} \mathrm{~L}^{-1}\right)$ in glucose solution $\mathrm{pH} 2.71$ within $60 \mathrm{~h}$ (rest glucose, $4.7 \mathrm{~g} \mathrm{~L}^{-1}$ ) and into a pool of five first washing fluids.

\begin{tabular}{ccc}
\hline Carboxylic Acids & In Glucose Solution & In the First Wash \\
\hline & Aliphatic acids \\
\hline Citric & 766 & $\mathrm{ND}$ \\
Fumaric & 1340 & $\mathrm{ND}$ \\
Glycolic & 150 & $\mathrm{ND}$ \\
Malic & 1800 & $\mathrm{ND}$ \\
Malonic & 1340 & 230 \\
Succinic & 8415 & $\mathrm{ND}$ \\
Tartaric & 105 & \\
\multicolumn{3}{c}{} \\
\hline Benzoic & Aromatic acids & 4.4 \\
Gallic & $<15$ & $<5.6$ \\
\hline
\end{tabular}

$\mathrm{ND}$, not determined.

\subsection{Oxidation of Guaiacol by Basidiospore Suspensions of K. mutabilis in Erlenmeyer Flasks}

Activities of the aseptic, unwashed, and exolaccase-deficient Kmt spores (Table 2) discharged immediately into the $\mathrm{N}$-free and high-purity glucose and guaiacol media (Tables 1 and 6) were followed by analyzing $0.3-\mathrm{mL}$ aliquots. No signs of germination and significant exoenzymatic activities were recorded at $2 \mathrm{~d}$. Germ tubes 15 to $>35 \mu \mathrm{m}$ long in $<1 \%$ of the spores had developed at $7 \mathrm{~d}$ in the glucose, guaiacol-only, and glucose/guaiacol media but dropped to a visually estimated $10 \%$ in the presence of ABTS. The contemporary production of the reddish-brown guaiacol transformation products peaking in absorbance at $470 \mathrm{~nm}$ seemed to slow down to a temporary plateau concentration from 7 to $11 \mathrm{~d}$. Their concentration in the guaiacol-only treatment surpassed that in glucose/guaiacol medium by a factor of four (Table 6). Accordingly, activities of polyphenoloxidases expressed in the ABTS assay and the respective release of (enzyme) proteins were greatly stimulated by guaiacol and apparently repressed by the poorly consumed glucose. The solubilized protein reached the 5 -fold of the $1.1 \mathrm{~g} \mathrm{~kg}^{-1}$ found inside and outside the resting spore itself (compare Table 2).

Table 6. Activity ranges of unwashed and aseptically germinating K. mutabilis basidiospores in $6 \mathrm{~mL}$ of high-purity solutions of glucose, guaiacol, and ABTS determined at 11 to $12 \mathrm{~d}(n=3-4)$.

\begin{tabular}{|c|c|c|c|c|c|c|}
\hline $\begin{array}{l}\text { Spore Incubation } \\
\text { Medium Amended } \\
\text { with }\left(L^{-1}\right)\end{array}$ & $\begin{array}{l}\text { Relative } \\
\text { Mycelial } \\
\text { Quantity }\end{array}$ & $\begin{array}{c}\text { Plateau } \\
\text { Concentr. of } \\
\text { Product } \mu \mathrm{M}\end{array}$ & $\begin{array}{c}\text { Enzymatic ABTS } \\
\text { Oxidation in } \mu \text { M Per53 } \\
\text { h }^{b} \text { Per Min }{ }^{a}\end{array}$ & $\begin{array}{c}\text { Protein } \\
\text { Released } \mathbf{g ~ k g}^{-1} \\
\text { Spores }\end{array}$ & $\begin{array}{c}\text { Rest } \\
\text { Glucose } \\
\mathrm{g} \mathrm{L}^{-1}\end{array}$ & $\begin{array}{c}\text { Mean Final pH } \\
\text { of Spore } \\
\text { Medium }\end{array}$ \\
\hline \multicolumn{7}{|c|}{ Spore load 3-4 mg per flask $\left(0.5-0.67 \mathrm{~g} \mathrm{~L}^{-1}\right)$} \\
\hline Glucose $5 \mathrm{~g}$ & 1 & & $3.4-35$ & $0.6-1.7^{2}$ & $2.5-3^{2}$ & 2.6 \\
\hline Guaiacol $133 \mathrm{mg}$ & 1.3 & $64-133^{1}$ & $0.7-1.3^{1}$ & $4.4-5.3^{1}$ & $0^{1}$ & 2.8 \\
\hline Glucose/guaiacol & $0.8-1.7$ & $16-25^{2}$ & $0.14^{2}$ & $1.8-3.0^{2}$ & $3.5-3.8^{2}$ & 2.7 \\
\hline ABTS $224 \mathrm{mg}$ & $<0.1$ & $1.9-47$ & $\begin{array}{ll}\text { ND } & \text { ND }\end{array}$ & ND & 0 & \\
\hline Glucose/ABTS & $<0.1$ & $2.3-67$ & ND & ND & $4.5-5$ & \\
\hline Glucose $5 \mathrm{~g}$ & $2^{c}$ & & $2.3-6.1^{\mathrm{c}}$ & & & $3.8^{\mathrm{c}}$ \\
\hline
\end{tabular}

${ }^{a}$ Enzyme activities $\left(\mu \mathrm{M} \mathrm{min}^{-1}\right)$ are re-calculated for $100 \%$ of spore incubation medium in the reaction mixture. ${ }^{\mathrm{b}}$ Values obtained with $0.33 \mathrm{~mL}$ of spore incubation medium in $1 \mathrm{~mL}$ of reaction mixture. ${ }^{c}$ Mycelium with aerial hyphae on the incubation medium. Data ranges with different superscript numbers in the guaiacol treatments differ significantly at $p \leq 0.05$. Detection limits, $0.3-0.5 \mu \mathrm{M}$ for guaicol and 56-83 nM for ABTS transformation products. $\mathrm{ND}$, not determined. Blanks, no corresponding values available. 
Comparable quantities of stunting mycelia represented by clusters of germinated spores were formed in the presence of glucose as well as of guaiacol-only (Table 6). The acidification of the incubation media to $\mathrm{pH}$ values of 2.6 to 2.8 that was started by non-germinated spores within $0-12 \mathrm{~h}$ (Figure 4) proceeded both in the presence of external glucose as well as pure guaiacol. The apparent spore-internal perception and metabolization of guaiacol should commence with the cleavage of its aromatic ring. Activities of the respective dioxygenases in milled homogenates of both spore sources, however, could not be shown.

\subsection{Oxidation of ABTS by Basidiospore Suspensions of K. mutabilis in Erlenmeyer Flasks}

In reference to the control solution of pure ABTS, the small spore lots of $<0.3 \mathrm{mg}\left(0.5 \mathrm{~g} \mathrm{~L}^{-1}\right)$ suspended in ABTS-only and glucose/ABTS solutions did not raise the absorbance at $\mathrm{A}_{420}$ over those in the controls by $6 \mathrm{~d}$ and displayed no PO activities from the spore surface. At $9 \mathrm{~d}$, one sample of the quadruplicate glucose/ABTS treatment had oxidized 66.7 of the $408 \mu \mathrm{M}$ ABTS provided (Table 6 ) and harboured sparse clusters of germinated spores. At $12 \mathrm{~d}$, spore germination in the presence of ABTS-only and glucose/ABTS was common, with the production of ABTS ${ }^{\bullet+}$ stagnating at $1.9-67 \mu \mathrm{M}$ to the advantage of glucose-containing samples (Table 6). This early plateau formation in the oxidation of $\mathrm{ABTS}_{\text {to }} \mathrm{ABTS}^{\bullet+}$ was not due to its further conversion to the red-coloured ABTS dication $\left(\mathrm{ABTS}^{2+}\right)$ [58] or to the final degradation of the ABTS molecule itself [59].

In two samples of a quadruplicate control treatment, the sparsely germinated spores had formed mats of aerial mycelium up to $10 \times 14 \mathrm{~mm}$ on pure glucose medium at $38 \mathrm{~d}$. The samples displayed the outstanding enzymatic activities of 2.3 and $6.1 \mu \mathrm{M} \mathrm{min}^{-1}$ in the ABTS assay (Table 6).

\subsection{HPLC-MS Analysis of Guaiacol Oligomers in Cuvette Cultures of K. mutabilis Spores}

In re-examining laccase-catalyzed guaiacol (M 124.14) transformation products, $12 \mathrm{mg}$ aseptically collected spores were incubated in $2 \mathrm{~mL}$ of guaiacol-amended $0.05 \mathrm{M} \mathrm{KH}_{2} \mathrm{PO}_{4}$ buffer $\mathrm{pH} 5\left(6 \mathrm{~g} \mathrm{~L}^{-1}\right.$ of spores) under filtered air conditions. $\mathrm{A}_{470}$ absorbance values reached $0.157 \mathrm{in} 8 \mathrm{~d}$ of incubation. Mass spectral analyses indicated the presence of a spore-catalyzed guaiacol dimer (M 246) and a trimer (368) of two tetramers (490) distinguished by retention times of 27.8 and $28.6 \mathrm{~min}$, and of a dimeric orthoquinone (260) (compare [60-63] for structural analogues). Unique compounds of MW 206 and 298 also appeared in notable concentrations. Tetraguaiacol (488) consisting of two C-O-O-C coupled dimers and immediately metabolizable guaiacol moieties $<\mathrm{M} 124.14$ were not detected.

\section{Discussion}

\subsection{Organic Resources and Protective Substances of Basidiospores}

Apart from the ubiquitous lipids [16,17], intrinsic carbohydrates were the major energy resources of spores determined to act in solutions of poorly metabolizable chemicals such as guaiacol and ABTS. They reached $160 / 15 \mathrm{~g} \mathrm{~kg}^{-1}$ sucrose and $97 / 6.8 \mathrm{~g} \mathrm{~kg}^{-1}$ xylose equivalents in spores of Stru and Kmt, respectively (Table 2). Surprising amounts of 7.3/9.7 $\mathrm{g} \mathrm{kg}^{-1}$ hexose sugars (Figure 3) corresponding with $4 / 39 \%$ of the total content were washed from outside the free-fallen spores and could possibly not be rated as accidental smear contaminants. The concentrations ranged in the order of those given for basidiospores of Agaricus bisporus [17] and Ganoderma lucidum [18]. Intrinsic soluble Bradford proteins [51] amounted to $12.6 / 0.9 \mathrm{~g} \mathrm{~kg}^{-1}$ of dry Stru/Kmt spores (Table 2) and differed apparently from the cell-wall bound compounds that respond in spores of Pisolithus microcarpus to staining [19]. In herb tissues, Bradford-protein values as reported in this study reached hardly $25 \%$ of those determined by the Kjeldahl method (unpublished). Spore external proteins were negligible.

Few reference values have been reported for spore-internal soluble phenols (Table 2) which may help in preserving the spore integrity in the field and on exposure to chemicals in biocatalytic applications. In spores of P. microcarpus, the presence of phenols could not be ascertained by staining [19]. From spores of $A$. bisporus, $p$-coumaric and the non-phenolic cinnamic acid were extracted [18]. In the 
spores of Stru and Kmt, four-step washings could not overcome the persistence of external phenolics (Table 2) as they may be part of the polyphenolic spore coat melanins which protect against oxidants, free radicals, and UV and gamma irradiation [64,65]. Phenolics are common to plants. Mycelia and sporocarps of most wild mushrooms are sources of hydroxylated benzoic and cinnamic acid derivatives, flavonoids, and tannins e.g., [66-68] with variable antibacterial properties [66]. They are constitutive antimicrobials and (oxygen) radical scavengers or are formed in response to wounding and pathogen ingress [69]. Cultivated mushrooms contained 31-63/0.05-1.57 $\mathrm{mg} \mathrm{kg}^{-1} \mathrm{DW}$ in the gallic/benzoic acids [70] found in spores of S. rugoso-annulata (Table 5). Total phenols in sporocarps ranged 2.8-6.3 $\mathrm{g} \mathrm{kg}^{-1} \mathrm{DW}[71]$ and surpassed the spore-typical concentrations.

\subsection{Polyphenoloxidases and Their Metal Co-Factors in Resting Spores}

True functional endolaccase was the sole polyphenoloxidase from inside the milled spores and was surprisingly high in those of Stru and marginal in those of $\mathrm{Kmt}$ (Table 2). Intrinsic tyrosinases and peroxidases for potential biocatalytic reactions were not detected. Exolaccases at $6 \%$ of the total activity could even be washed from free-fallen spores of Stru but virtually not from those of Kmt. Laccase may contribute to melanin synthesis [72,73] and commonly to the pigmentation of ascomycete conidia $[74,75]$. Laccase glycoproteins are also structural components of endospore coats in Bacillus subtilis $[73,76]$. This does not seem to apply to spores of Stru. The rapid downwash of the proteins (Table 2) points to constitutive or accidental surface coatings which mimic laccase activity of the resting spore.

The metallome of Kmt basidiospores was actively adapted [43] to the concentration spans which ensure the vigorous and metal stress-free development of seedlings in seed crops $[55,56]$ with which fungi share the common geochemical environment. Up to $55 / 13 \%$ of the total $\mathrm{Ca} / \mathrm{Cu}$ stock was located on the spore surface (Tables 1 and 3). The spores' mineral stock could thus be high enough to equip their enzyme proteins with metal cofactors and to ensure their independence of external minerals during the initial metabolic steps in high-purity solutions (Table 1). Unwashed spores of Stru combined $20 \mathrm{mg} \mathrm{kg}^{-1} \mathrm{Cu}(0.32 \mathrm{mmol}$ ) (Table 3$)$ with $12.6 \mathrm{~g} \mathrm{~kg}^{-1}$ of intrinsic soluble protein (Table 2). An equimolar $\mathrm{Cu}$ concentration would come to $0.1575 \mathrm{mmol}$ if the entire protein would be made up of sugar-free laccase M 80,000. To equip the protein with the fourfold molar concentration of its metal cofactor, $0.63 \mathrm{mmol} \mathrm{Cu}$ cations had to be provided. This means in turn that the small (glyco)protein fractions of endolaccases in both spore sources should be saturated by the internally available catalytic $\mathrm{Cu}$ cations compare $[32,37-40]$ to ensure their functionality.

\subsection{Early Metabolic Activities of Basidiospores and Their Partial Germination}

Exuded aliphatic and aromatic carboxylates determined for the unwashed and non-germinated spores of Stru in 1-cm cuvettes (Table 5) acidified a glucose medium by $0.7 \mathrm{pH}$ units even within $12 \mathrm{~h}$ of imbibition and reached values of $\mathrm{pH} 2.6$ (Figure 4). Spore incubations in water or the guaiacol solution did not result in $\mathrm{pH}$ drops. In contrast, unwashed $\mathrm{Kmt}$ spores acidified their media in the presence of glucose, glucose/guaiacol, or the not immediately metabolizable guaiacol itself (Table 6, Figure 4). The release of carboxylates apparently by both non-germinated spore sp. at zero time thus seemed to be linked with perception or uptake of (potential) external nutrients at least in regard to glucose. This indicated the early functionality of the enzyme systems involved in tricarboxylic acid and the glyoxylate cycle and in the subsequent enzymatic derivation of their primary carboxylates to glycolate, malonate, and tartrate in the formation of further carbon skeletons for amino acids [22].

The slight $\mathrm{pH}$ increases in water as incubation medium (Figure 4 ) are reminiscent of alkalinations caused by $\mathrm{H}^{+}$consuming decarboxylations of (spore external) carboxylic acids (Table 5) [77] and the generation of $\mathrm{OH}^{-}$during their oxidative degradation [78,79]. The release of internal and external aromatic carboxylates from the stock of total phenols (Tables 2 and 5) may be accidental. Gallic acid with its moderate antimicrobial activity is more notorious for its inhibitory effects on laccases $>$ tyrosinases [80]. It is transformed to pyrogallol by gallate decarboxylase [81] or oxidatively degraded 
to aliphatic carboxylates by aromatic-ring cleavage [82] to enter the tricarboxylic acid cycle. The early release of carboxylate ligands active in the mobilization of essential trace minerals [83] and active in the fragmentation of soil humic colloids into metabolizable units [84] confers considerable ecological advantages to the pre-germination spore.

In the glucose solution, the production of germ tubes and floating mycelia represented by germinated-spore clusters from days 3 to 5 was $4-5$ times as high in unwashed than in washed spores (Table 4), although their germination rates were congruent with the estimated $35 \%$. In water, spore external compounds such as the 7.3-9.7 $\mathrm{g} \mathrm{kg}^{-1}$ hexose sugars corresponded with a concentration of $0.04 \mathrm{~g} \mathrm{~L}^{-1}$ in the incubation medium (Table 2). This improved the minor germination rate of $<<1 \%$ o in both spore sp. visibly (Table 4). Washed spores at least of Stru germinated principally if set back solely to their internal resources. Some nutritional support by aerial $\mathrm{CO}_{2}$-carbon $[24,31]$ should not be excluded.

\subsection{Expression of Exo-Oxidoreductases Was Confined to the Germinating K. mutabilis Basidiospore}

The exolaccase deficient $\mathrm{Kmt}$ spores in Erlenmeyer flasks at $0.5-0.67 \mathrm{~g} \mathrm{~L}^{-1}$ formed comparable quantities of germinated-spore clusters on $\mathrm{N}$-free glucose, pure guaiacol, and glucose/guaiacol media between 2 to $11 \mathrm{~d}$ and acidified their incubation media to the same extent by the apparent release of carboxylates starting almost at zero time (Table 6, see above). Contemporarily, the oxidation of guaiacol commencing with spore germination, the appearance of exo-polyphenoloxidase activities, and the exudation of (enzyme-glyco-) proteins was higher in the pure guaiacol treatment and apparently inhibited by glucose (Table 6). Exuded proteins up to $4.4-5.3 \mathrm{~g} \mathrm{~kg}^{-1}$ surpassed the load of $0.168 \mathrm{~g} \mathrm{~kg}^{-1}$ retrievable from outside the spores themselves considerably (Table 2). The presence of non-consumed glucose at 2.5-3.8 $\mathrm{g} \mathrm{L}^{-1}$ in the incubation media makes spores persist in the trophophase state which is denoted by a significantly repressed laccase activity. The transition from fungal tropho- to idiophase with the depletion of internal and the absence of external carbon leads to the enhanced formation of laccase $[85,86]$ due to the outset of fungal proteolysis [86] and the production of secondary metabolites [87].

Spore stocks $<0.05 \mathrm{~g} \mathrm{~L}^{-1}$ germinated, too, on a pure solution of the heterocyclic ABTS whose oxidative transformation ended in the state of $\mathrm{ABTS}^{\bullet+}$ to indicate that its $\mathrm{C}, \mathrm{N}$, and $\mathrm{S}$ constituents did not immediately contribute to spore nutrition (Table 6). Nevertheless, germination of the submerged spores and the enzymatic transformation of guaiacol and ABTS came finally to a standstill in all treatments within 12-25 d and may indicate the depletion of the spores' non-structural $\mathrm{N}$ stock. Furthermore, $\mathrm{pH}$ conditions between 2.6-2.8 may not only be detrimental to spore germination. It was shown that $\mathrm{pH}$ values between 2.1-2.2 deactivated $\mathrm{Kmt}$ laccase completely within $4-5 \mathrm{~d}$ [88]. In the case of Kmt spores that formed aerial mycelia on the surface of glucose solution, access to air resulted in higher $\mathrm{pH}$ conditions and an enhanced production of oxidoreductase enzymes (Table 6) that seemed to comprise tyrosinase and MnP activities typical of $\mathrm{Kmt}$ mycelia [89].

$\mathrm{Kmt}$ spores incubated submerged in non-glucose media of Erlenmeyer flasks did not display energy deficits in spite of their apparent idiophase state. Guaiacol molecules (M 124.14) smaller than those of glucose (M 180.16) should readily be taken up but should not enter the energy generating pathways prior to aromatic-ring cleavings. The respective spore internal enzyme systems of the meta-cleavage pathway, catechol 2,3- and protocatechuate 4,5-dioxygenase [80], were not constitutively expressed in the spore homogenates. In reactions catalyzed by lignin peroxidase, incorporation of $\mathrm{O}_{2}$ from $\mathrm{H}_{2} \mathrm{O}$ by radical reactions could also result in cleavages of aromatic rings [90]. Spore-external activities represented mainly by laccase-like enzymes caused guaiacol molecules exclusively to polymerize (Section 3.7) after the typical one-electron oxidations [32,37-40] to block their immediate metabolization. Dioxygenases of the meta-cleavage pathway were generally wide-spread in outdoor fungal mats [50] and their formation by the germinating spore should not be excluded. Consumption of the aromatic compound could thus contribute to the higher activities of guaiacol versus guaiacol/glucose incubated spores (Table 6). 
Beneficial effects of ABTS on spore metabolic activities remain obscure. The compound of $\mathrm{M}$ 548.68 is oxidized by laccases (and peroxidases) such as above to the stable ABTS ${ }^{\bullet+}$ by one-electron abstraction. Its subsequent oxidation to $\mathrm{ABTS}^{2+}$ by the enzymes alone is controversial [91,92]. It was, however, shown that enzyme-free $\mathrm{ABTS}^{\bullet+}$ preparations are reduced to ABTS during their abiotic oxidation of low-MW extractives from lignocelluloses (and of other organic traces) to redox mediating radicals. The radicals, in turn, transform the remaining $\mathrm{ABTS}^{\bullet+}$ to the red $\mathrm{ABTS}^{2+}$ compound, to red protein/ABTS adducts, and to further ABTS moieties [93]. The dication is accessible to slow decay by inorganic peroxides [64] but may end in red azo dye fragments [93].

\section{Conclusions}

Washings revealed the non-existence of the expected "externally clean" free-fallen spores. Beside the antimicrobial and structural phenolics, several surface carbohydrates, proteins, minerals, and aliphatic and aromatic carboxylates were washed off. Surface exolaccase mimicked oxidative activities of the resting spores. Intrinsic constituents enabled washed basidiospores of S. rugoso-annulata to form stagnating germ tubes at a rate of $<1 \%$ o in bideionized water. Germination was promoted by their surface constituents. Spores of K. mutabilis showed comparable rates of germination $(<1 \%$ o) on $\mathrm{N}$-free incubation media with glucose or the not immediately utilizable aromatic/heterocyclic substances, guaiacol and ABTS in standing liquid culture and acidified the media to $\mathrm{pH}$ 2.6-2.8 apparently with carboxylic acids that are known to mobilize minerals and organic nutrients from soil humic substances. With the formation of extensive germ tubes, proteins and functional polyphenoloxidase(s) derived from intrinsic deposits of nitrogen and reactive $\mathrm{Cu}$ cations were released. The dominating true laccase then oxidized ABTS to the temporary dead-end product $\mathrm{ABTS}^{\bullet+}$ and formed polymers, but no low-MW fragments from guaiacol. It is postulated that the formation of first mycelia and the resulting release of oxidoreductases proceeded with the spores' internal and surface-bound resources. This confers some plant seed-like autonomy to basidiospores of wood-decay fungi in the initial attack on lignocelluloses devoid of easily accessible $\mathrm{N}$ and $\mathrm{C}$ sources. This can be seen as an ecological and competitive advantage in the colonization of poor substrates in the field. The results open chances especially for idiophase spores to transform or (co-)polymerize those aromatic chemicals in liquid state fermentations (and in the absence of sugars) which are substrates of the highly efficient oxidoreductase enzymes of basidiomycetes. Therefore, commercially available spores of the indoors cultivated mushrooms Agaricus bisporus and Pleurotus ostreatus will be subjects of further studies into potential biocatalytic applications due to their year-round availability.

Author Contributions: In this cooperative work, G.G. primarily performed the microbiological part whereas K.-D.V. contributed chemical analyses. The script was elaborated in mutual consultation. All authors have read and agreed to the published version of the manuscript.

Funding: This work received no funding.

Acknowledgments: The authors are obliged to Michael Reichelt, Max-Planck-Institute of Chemical Ecology, Department of Biochemistry, in Jena, and to Volker Schulz, recently from Food GmbH Jena, Germany, for the contribution of HPLC analytical data.

Conflicts of Interest: The authors declare no conflict of interest.

\section{References}

1. Zamoum, M.; Goudjal, Y.; Sabaou, N.; Mathieu, F.; Zitouni, A. Development of formulations based on Streptomyces rochei strain PTL2 spores for biocontrol of Rhizoctonia solani damping-off of tomato seedlings. Biocontrol Sci. Technol. 2017, 27, 723-738. [CrossRef]

2. Fravel, D.R. Commercialization and implementation of biocontrol. Annu. Rev. Phytopathol. 2005, 43, 337-359. [CrossRef] [PubMed]

3. Ramachandran, S.; Larroche, C.; Pandey, A. Production of spores. In Current Developments in Solid-State Fermentation; Pandey, A., Soccol, C.R., Larroche, C., Eds.; Springer Asiatech Publishers, Inc.: New Delhi, India, 2008; pp. 230-252. 
4. Charudattan, R. Biological control of weeds by means of plant pathogens: Significance for integrated weed management in modern agro-ecology. BioControl 2001, 46, 229-260. [CrossRef]

5. Virtanen, V.; Nyyssölä, A.; Vuolanto, A.; Leisola, M.; Seiskari, P. Bioreactor for solid-state cultivation of Phlebiopsis gigantea. Biotechnol. Lett. 2008, 30, 253-258. [CrossRef] [PubMed]

6. El-Bendary, M.A. Production of mosquitocidal Bacillus sphaericus by solid state fermentation using agricultural wastes. World J. Microbiol. Biotechnol. 2010, 26, 153-159. [CrossRef]

7. Sansinenea, E.; Ortiz, A. Secondary metabolites of soil Bacillus spp. Biotechnol. Lett. 2011, 33, $1523-1538$. [CrossRef]

8. Van Breukelen, F.R.; Haemers, S.; Wijffels, R.H.; Rinzema, A. Bioreactor and substrate selection for solid-state cultivation of the malaria mosquito control agent Metarhizium anisopliae. Process. Biochem. 2011, 46, 751-757. [CrossRef]

9. Juwarkar, A.A.; Jambhulkar, H.P. Phytoremediation of coal mine spoil dump through integrated biotechnological approach. Biores. Technol. 2008, 99, 4732-4741. [CrossRef]

10. Ram, L.C.; Srivastava, N.K.; Jha, S.K.; Sinha, A.K.; Masto, R.E.; Selvi, V.A. Management of lignite fly ash for improving soil fertility and crop productivity. Environ. Manag. 2007, 40, 438-452. [CrossRef]

11. Mussatto, S.I.; Teixeira, J.A. Lignocellulose as raw material in fermentation processes. In Current Research, Technology and Education Topics in Applied Microbiology and Microbial Biotechnology; Méndez-Vilas, A., Ed.; Formatex: Badajoz, Spain, 2010; pp. 897-909.

12. Tengerdy, R.P.; Szakacs, G. Bioconversion of lignocellulose in solid substrate fermentation. Biochem. Eng. J. 2003, 13, 169-179. [CrossRef]

13. Wang, L.; Yang, S.-T. Solid state fermentation and its applications. In Bioprocessing for Value-Added Products from Renewable Resources; Yang, S.-T., Ed.; Elsevier B.V.: Amsterdam, The Netherlands, 2007; pp. 465-489.

14. Larroche, C.; Gros, J.B. Special transformation processes using fungal spores and immobilized cells. Adv. Biochem. Eng. Biotechnol. 1997, 55, 179-220. [PubMed]

15. Ruch, D.G.; Motta, J.J. Ultrastructure and cytochemistry of dormant basidiospores of Psilocybe cubensis. Mycologia 1987, 79, 387-398. [CrossRef]

16. Ruch, D.G.; Burton, K.W.; Ingram, L.A. Occurrence of the glyoxylate cycle in basidiospores of homobasidiomycetes. Mycologia 1991, 83, 821-825. [CrossRef]

17. Feofilova, E.P.; Tereshina, V.M.; Garibova, L.V.; Zav'yalova, L.A.; Memorskaya, A.S.; Maryshova, N.S. Germination of basidiospores of Agaricus bisporus. Appl. Biochem. Microbiol. 2004, 40, 186-191. [CrossRef]

18. Heleno, S.A.; Barros, L.; Martins, A.; Queiroz, M.J.R.P.; Santos-Buelga, C.; Ferriera, I.C.F.R. Fruiting body, spores and in vitro produced mycelium of Ganoderma lucidum from Northeast Portugal: A comparative study of the antioxidant potential of phenolic and polysaccharidic extracts. Food Res. Int. 2012, 46, 135-140. [CrossRef]

19. Narvaes da Rocha Campos, A.; Dutra Costa, M. Histochemistry and storage of organic compounds during basidiosporogenesis in the ectomycorrhizal fungus Pisolithus microcarpus. World J. Microbiol. Biotechnol. 2010, 26, 1745-1753. [CrossRef]

20. Hayer, K.; Stratford, M.; Archer, D.B. Structural features of sugars that trigger or support conidial germination in the filamentous fungus Aspergillus niger. Appl. Environ. Microbiol. 2013, 79, 6924-6931. [CrossRef]

21. Krijgsheld, P.; Bleichrodt, R.; Van Veluw, G.J.; Wang, F.; Muller, W.H.; Dijksterhuis, J.; Wösten, H.A.B. Development in Aspergillus. Stud. Mycol. 2013, 74, 1-29. [CrossRef]

22. Mengel, K. Ernährung und Stoffwechsel der Pflanze, 7th ed.; Gustav Fischer: Jena, Germany, 1991.

23. Bachofen, R.; Rast, D. Carboxylierungs-reaktionen in Agaricus bisporus. III. Pyruvat und Phosphoenolpyruvat als $\mathrm{CO}_{2}$-Acceptoren. Arch. Microbiol. 1968, 60, 217-234.

24. Mog, T.P.; Morton, H.L. Carbon dioxide stimulates germination of basidiospores of Polyporus dryophilus and Fomes rimosus. Phytopathology 1970, 60, 1305.

25. Harman, G.E.; Mattick, L.R.; Nash, G.; Nedrow, B.L. Stimulation of fungal spore germination and inhibition of sporulation in fungal vegetative thalli by fatty acids and their volatile peroxidation products. Canad. J. Bot. 1980, 58, 1541-1547. [CrossRef]

26. Brown, T.S., Jr.; Merrill, W. Germination of basidiospores of Fomes applanatus. Phytopathology 1973, 63, 547-550. [CrossRef] 
27. Deising, H.; Nicholson, R.L.; Haug, M.; Howard, R.J.; Mengden, K. Adhesion pad formation and the involvement of cutinase and esterases in the attachment of uredospores to the host cuticle. Plant. Cell 1992, 4, 1101-1111. [CrossRef] [PubMed]

28. Money, N.P. Mechanics of invasive fungal growth and the significance of turgor in plant infection. In Molecular Genetics of Host-Specific Toxins in Plant Disease; Kohmoto, K., Yoder, O.C., Eds.; Kluwer Academic: Dordrecht, The Netherlands, 1998; pp. 261-271.

29. Moreau, R.A.; Seibles, T.S. Production of extracellular enzymes by germinating cysts of Phytophthora infestans. Canad. J. Bot. 1985, 63, 1811-1816. [CrossRef]

30. Hyde, J.M.; Walkinshaw, C.H. Ultrastructure of basidiospores and mycelium of Lenzites saepiaria. J. Bacteriol. 1966, 92, 1218. [CrossRef]

31. Scheld, H.W.; Perry, J.J. Basidiospore germination in the wooddestroying fungus Lenzites saepiaria. J. Gen. Microbiol. 1970, 60, 9-21. [CrossRef]

32. Passardi, F.; Bakalovic, N.; Teixeira, F.K.; Margis-Pinheiro, M.; Penel, C.; Dunand, C. Prokaryotic origins of the non-animal peroxidase superfamily and organelle-mediated transmission to eukaryotes. Genomics 2007, 89, 567-579. [CrossRef]

33. Lu, Y.; Yeung, N.; Sieracki, N.; Marshall, N.M. Design of functional metalloproteins. Nature 2009, 460, 855-862. [CrossRef]

34. Waldron, K.J.; Robinson, N.J. How do bacterial cells ensure that metalloproteins get the correct metal? Nat. Rev. Microbiol. 2009, 7, 25-35. [CrossRef]

35. Andreini, C.; Bertini, I.; Cavallaro, G.; Holliday, G.L.; Thornton, J.M. Metal ions in biological catalysis: From enzyme databases to general principles. J. Biol. Inorg. Chem. 2008, 13, 1205-1218. [CrossRef]

36. Waldron, K.J.; Rutherford, J.C.; Ford, D.; Robinson, N.J. Metalloproteins and metal sensing. Nature 2009, 460, 823-830. [CrossRef] [PubMed]

37. Gramss, G. Potential contributions of oxidoreductases from alfalfa plants to soil enzymology and biotechnology: A review. J. Nat. Sci. Sust. Technol. 2012, 6, 169-223.

38. Hofrichter, M.; Ullrich, R.; Pecyna, M.J.; Liers, C.; Lundell, T. New and classic families of secreted fungal heme peroxidases. Appl. Microbiol. Biotechnol. 2010, 87, 871-897. [CrossRef] [PubMed]

39. Wong, D.W.S. Structure and action mechanism of ligninolytic enzymes. Appl. Biochem. Biotechnol. 2009, 157, 174-209. [CrossRef] [PubMed]

40. Nikolaivitis, E.; Dimarogona, M.; Karagiannaki, I.; Chalima, A.; Fishman, A.; Topakasa, E. Versatile fungal polyphenol oxidase with chlorophenol bioremediation potential: Characterization and protein engineering. Appl. Environ. Microbiol. 2018, 84, e01628-18. [CrossRef] [PubMed]

41. Hölker, U.; Dohse, J.; Höfer, M. Extracellular laccases in ascomycetes Trichoderma atroviride and Trichoderma harzianum. Folia Microbiol. 2002, 47, 423-427. [CrossRef]

42. Gramss, G. Kuehneromyces mutabilis. In The Biology and Cultivation of Edible Mushrooms; Chang, S.T., Hayes, W.A., Eds.; Academic Press: New York, NY, USA, 1978; pp. 423-443.

43. Gramss, G.; Voigt, K.-D. Clues for regulatory processes in fungal uptake and transfer of minerals to the basidiospore. Biol. Trace Elem. Res. 2013, 154, 140-149. [CrossRef]

44. Günther, T.; Sack, U.; Hofrichter, M.; Lätz, M. Oxidation of PAH and PAH-derivatives by fungal and plant oxidoreductases. J. Basic Microbiol. 1998, 38, 113-122. [CrossRef]

45. Sterjiades, R.; Dean, J.F.D.; Eriksson, K.-E.L. Laccase from sycamore maple (Acer pseudoplatanus) polymerizes monolignols. Plant. Physiol. 1992, 99, 1162-1168. [CrossRef]

46. Givaudan, A.; Effosse, A.; Faure, D.; Potier, P.; Bouillant, M.-L.; Bally, R. Polyphenol oxidase in Azospirillum lipoferum isolated from rice rhizosphere: Evidence for laccase activity in nonmotile strains of Azospirillum lipoferum. FEMS Microbiol. Lett. 1993, 108, 205-210. [CrossRef]

47. Tremolieres, M.; Bieth, J.G. Isolation and characterization of the polyphenoloxidase from senescent leaves of black poplar. Phytochemistry 1984, 23, 501-505. [CrossRef]

48. Périé, F.H.; Gold, M.H. Manganese regulation of manganese peroxidase expression and lignin degradation by the white rot fungus Dichomitus squalens. Appl. Environ. Microbiol. 1991, 57, 2240-2245. [CrossRef] [PubMed]

49. Wariishi, H.; Valli, K.; Gold, M.H. Manganese(II) oxidation by manganese peroxidase from the basidiomycete Phanerochaete chrysosporium. Kinetic mechanism and role of chelators. J. Biol. Chem. 1992, 267, 23688-23695.

50. Gramss, G. Activity of oxidative enzymes in fungal mycelia from grassland and forest soils. J. Basic Microbiol. 1997, 37, 407-423. [CrossRef] 
51. Bradford, M.M. A rapid and sensitive method for the quantitation of microgram quantities of protein utilizing the principle of protein-dye binding. Anal. Biochem. 1976, 72, 248-254. [CrossRef]

52. Dubois, M.; Gilles, K.A.; Hamilton, J.K.; Rebers, P.A.; Smith, F. Colorimetric method for determination of sugars and related substances. Anal. Chem. 1956, 28, 350-356. [CrossRef]

53. Wackett, L.P.; Gibson, D.T. Rapid method for detection and quantitation of hydroxylated aromatic intermediates produced by microorganisms. Appl. Environ. Microbiol. 1983, 45, 1144-1147. [CrossRef]

54. Harkin, J.M.; Larsen, M.J.; Obst, J.R. Use of syringaldazine for detection of laccase in sporophores of wood rotting fungi. Mycologia 1974, 66, 469-476. [CrossRef]

55. Gramss, G.; Voigt, K.-D. Regulation of heavy metal concentrations in cereal grains from uranium mine soils. Plant. Soil 2013, 364, 105-118. [CrossRef]

56. Gramss, G.; Voigt, K.-D. Stability of the inherent target metallome in seed crops and a mushroom grown on soils of extreme mineral spans. Agronomy 2016, 6, 14. [CrossRef]

57. Schachtschabel, P.; Blume, H.-P.; Brümmer, G.; Hartge, K.H.; Schwertmann, U. Lehrbuch der Bodenkunde, 14th ed.; Enke: Stuttgart, Germany, 1998.

58. Bourbonnais, R.; Leech, D.; Paice, M.G. Electrochemical analysis of the interactions of laccase mediators with lignin model compounds. Biochim. Biophys. Acta 1998, 1379, 381-390. [CrossRef]

59. Venkatasubramanian, L.; Maruthamuthu, P. Kinetics and mechanism of formation and decay of 2,2'-azinobis-(3-ethyl-benzothiazole-6-sulphonate) radical cation in aqueous solution by inorganic peroxides. Int. J. Chem. Kinet. 1989, 21, 399-421. [CrossRef]

60. Gierer, J.; Opara, A.E. Studies on the enzymatic degradation of lignin. The action of peroxidase and laccase on monomeric and dimeric model compounds. Acta Chem. Scand. 1973, 27, 2909-2922. [CrossRef]

61. Schmalzl, K.J.; Forsyth, C.M.; Evans, P.D. The reaction of guaiacol with iron(III) and chromium (VI) compounds as a model for wood surface modification. Wood Sci. Technol. 1995, 29, 307-319. [CrossRef]

62. Schmalzl, K.J.; Forsyth, C.M.; Evans, P.D. Evidence for the formation of chromium (III) diphenoquinone complexes during oxidation of guaiacol and 2,6-dimethoxyphenol with chromic acid. Polymer Degrad. Stabil. 2003, 82, 399-407. [CrossRef]

63. Simmons, K.E.; Minard, R.D.; Bollag, J.-M. Oxidative coupling and polymerization of guaiacol, a lignin derivative. Soil Sci. Soc. Am. J. 1988, 52, 1356-1360. [CrossRef]

64. Bell, A.A.; Wheeler, M.H. Biosynthesis and functions of fungal melanins. Annu. Rev. Phytopathol. 1986, 24, 411-451. [CrossRef]

65. López-Serrano, D.; Solano, F.; Sanchez-Amat, A. Identification of an operon involved in tyrosinase activity and melanin synthesis in Marinomonas mediterranea. Gene 2004, 342, 179-187. [CrossRef]

66. Alves, M.J.; Ferreira, I.C.F.R.; Froufe, H.J.C.; Abreu, R.M.V.; Martins, A.; Pintado, M. Antimicrobial activity of phenolic compounds identified in wild mushrooms, SAR analysis and docking studies. J. Appl. Microbiol. 2013, 1-12. [CrossRef]

67. Barros, L.; Dueñas, M.; Ferreira, I.C.F.R.; Baptista, P.; Santos-Buelga, C. Phenolic acids determination by HPLC-DAD-ESI/MS in sixteen different Portuguese wild mushrooms species. Food Chem. Toxicol. 2009, 47, 1076-1079. [CrossRef]

68. Kim, M.-Y.; Seguin, P.; Ahn, J.-K.; Kim, J.-J.; Chun, S.-C.; Kim, E.-H.; Seo, S.-H.; Kang, E.-Y.; Kim, S.-L.; Park, Y.-J.; et al. Phenolic compound concentration and antioxidant activities of edible and medicinal mushrooms from Korea. J. Agric. Food Chem. 2008, 56, 7265-7270. [CrossRef] [PubMed]

69. Nicholson, R.L. Phenolic compounds and their role in disease resistance. Annu. Rev. Phytopathol. 1992, 30, 369-389. [CrossRef]

70. Reis, F.S.; Martins, A.; Barros, L.; Ferreira, I.C.F.R. Antioxidant properties and phenolic profile of the most widely appreciated cultivated mushrooms: A comparative study between in vivo and in vitro samples. Food Chem. Toxicol. 2012, 50, 1201-1207. [CrossRef] [PubMed]

71. Barros, L.; Ferreira, M.-J.; Queiros, B.; Ferreira, I.C.F.R.; Baptista, P. Total phenols, ascorbic acid, $\beta$-carotene and lycopene in Portuguese wild edible mushrooms and their antioxidant activities. Food Chem. 2007, 103, 413-419. [CrossRef]

72. Faure, D.; Bouillant, M.L.; Bally, R. Isolation of Azospirillum lipoferum 4T Tn5 mutants affected in melanization and laccase activity. Appl. Environ. Microbiol. 1994, 60, 3413-3415. [CrossRef]

73. Hullo, M.-F.; Moszer, I.; Danchin, A.; Martin-Verstraete, I. CotA of Bacillus subtilis is a copper-dependent laccase. J. Bacteriol. 2001, 183, 5426-5430. [CrossRef] 
74. Clutterbuck, A.J. Absence of laccase from yellow-spored mutants of Aspergillus nidulans. J. Gen. Microbiol. 1972, 70, 423-435. [CrossRef]

75. Sugareva, V.; Härtl, A.; Brock, M.; Hübner, K.; Rohde, M.; Heinekamp, T.; Brakhage, A.A. Characterisation of the laccase-encoding gene abr2 of the dihydroxynaphthalene-like melanin gene cluster of Aspergillus fumigatus. Arch. Microbiol. 2006, 186, 345-355. [CrossRef]

76. Martins, L.O.; Soares, C.M.; Pereira, M.M.; Teixeira, M.; Costa, T.; Jones, G.H.; Henriques, A.O. Molecular and biochemical characterization of a highly stable bacterial laccase that occurs as a structural component of the Bacillus subtilis endospore coat. J. Biol. Chem. 2002, 277, 18849-18859. [CrossRef]

77. Barekzai, A.; Mengel, K. Effect of microbial decomposition of mature leaves on soil pH. J. Plant. Nutr. Soil Sci. 1993, 156, 93-94. [CrossRef]

78. Perez, J.; Jeffries, T.W. Roles of manganese and organic acid chelators in regulating lignin degradation and biosynthesis of peroxidases by Phanerochaete chrysosporium. Appl. Environ. Microbiol. 1992, 58, 2402-2409. [CrossRef] [PubMed]

79. Gramss, G.; Voigt, K.-D.; Bublitz, F.; Bergmann, H. Increased solubility of (heavy) metals in soil during microbial transformations of sucrose and casein amendments. J. Basic. Microbiol. 2003, 43, 483-498. [CrossRef] [PubMed]

80. Schomburg, D.; Salzmann, M.; Stephan, D. Enzyme Handbook; Springer: Berlin, Germany, 1994; Volume 1-10.

81. Bhat, T.K.; Singh, B.; Sharma, O.P. Microbial degradation of tannins-A current perspective. Biodegradation 1998, 9, 343-357. [CrossRef] [PubMed]

82. Field, J.A.; Lettinga, G. Biodegradation of tannins. In Metal Ions in Biological Systems. Degradation of Environmental Pollutants by Microorganisms and their Metalloenzymes; Sigel, H., Ed.; Marcel Dekker Inc.: New York, NY, USA, 1992; Volume 28, pp. 61-97.

83. Gramss, G.; Voigt, K.-D.; Bergmann, H. Mobilization of hazardous metals by plants growing in soils from uranium mining. In Uranium in the Aquatic Environment, Proceedings of the International Conference Uranium Mining and Hydrology III and the International Mine Water Association Symposium, Freiberg, Germany, 15-21 September 2002; Merkel, B.J., Planer-Friedrich, B., Wolkendorfer, C., Eds.; Springer: Berlin, Germany, 2002; pp. 521-528.

84. Piccolo, A.; Conte, P.; Spaccini, R.; Chiarella, M. Effects of some dicarboxylic acids on the association of dissolved humic substances. Biol. Fertil. Soils 2003, 37, 255-259. [CrossRef]

85. Belcarz, A.; Ginalska, G.; Kornillowicz-Kowalska, T. Extracellular enzyme activities of Bjerkandera adusta R59 soil strain, capable of daunomycin and humic acids degradation. Appl. Microbiol. Biotechnol. 2005, 68, 686-694. [CrossRef]

86. Rabinovich, M.L.; Bolobova, A.V.; Vasil'chenko, L.G. Fungal decomposition of natural aromatic structures and xenobiotics: A review. Appl. Biochem. Microbiol. 2004, 40, 1-17. [CrossRef]

87. Waites, M.J.; Morgan, N.L.; Rockey, J.S.; Higton, A.G. Industrial Microbiology. An Introduction; Blackwell Publishing: Oxford, UK, 2001.

88. Gramss, G. Aspects determining the dominance of Fomitopsis pinicola in the colonization of deadwood and the role of the pathogenicity factor oxalate. Forests 2020, 11, 290. [CrossRef]

89. Gramss, G.; Kirsche, B.; Voigt, K.-D.; Günther, T.; Fritsche, W. Conversion rates of five polycyclic aromatic hydrocarbons in liquid cultures of fifty-eight fungal species and the concomitant production of oxidative enzymes. Mycol. Res. 1999, 103, 1009-1018. [CrossRef]

90. Umezawa, T.; Higuchi, T. Mechanism of aromatic ring cleavage of $\beta$-O-4 lignin substructure models by lignin peroxidase. FEBS Lett. 1987, 218, 255-260. [CrossRef]

91. Jung, D. Immobilization of Enzymes on Mesoporous Supports and Their Application in Continuous-Flow Biotransformations. Ph.D. Thesis, University Erlangen-Nürnberg, Erlangen, Germany, 2012.

92. Morozova, O.V.; Shumakovich, G.P.; Shleev, S.V.; Yaropolov, Y.I. Laccase-mediator systems and their applications: A review. Appl. Biochem. Microbiol. 2007, 43, 523-535. [CrossRef]

93. Gramss, G. Reappraising a controversy: Formation and role of the azodication $\left(\mathrm{ABTS}^{2+}\right)$ in the laccase-ABTS catalyzed breakdown of lignin. Fermentation 2017, 3, 27. [CrossRef]

(C) 2020 by the authors. Licensee MDPI, Basel, Switzerland. This article is an open access article distributed under the terms and conditions of the Creative Commons Attribution (CC BY) license (http://creativecommons.org/licenses/by/4.0/). 